\title{
Building Information Modeling (BIM) in Iran: An Exploratory Study
}

\author{
M. Reza Hosseini ${ }^{1}$, Ehsan Azari ${ }^{2}$, Linda Tivendale ${ }^{3}$, Saeed Banihashemi ${ }^{4}$, and Nicholas Chileshe ${ }^{5}$ \\ ${ }^{1}$ Lecturer, School of Architecture and Built Environment, Deakin University, Geelong, Australia, \\ Email: reza.hosseini@deakin.edu.au (corresponding author). \\ ${ }^{2}$ BIM Specialist, Tehran Institute of Technology, Tehran, Iran, Email: azari.ehsan.iran@gmail.com \\ ${ }^{3}$ Lecturer, School of Architecture and Built Environment, Deakin University, Geelong, Australia, \\ Email: linda.tivendale@deakin.edu.au \\ ${ }^{4} \mathrm{PhD}$ Candidate, School of Built Environment, Faculty of Design, Architecture and Building, University of \\ Technology Sydney (UTS), Sydney, Australia, Email: Seyed.S.BanihashemiNamini@student.uts.edu.au \\ ${ }^{5}$ Senior Lecturer, School of Natural and Built Environments, University of South Australia, Adelaide, Australia, \\ Email: nicholas.chileshe@unisa.edu.au
}

\author{
Engineering Management \\ Excellent Paper of EPPM2015 Conference \\ Received December 18, 2015; received revision April 19, 2016; accepted April 21, 2016 \\ Available online May 30, 2016
}

\begin{abstract}
BIM has received considerable attention from academics and innovative construction companies in recent years within the Iranian context. However, there is a conspicuous lack of studies, which give a picture of the current state of BIM in Iran. To address this gap in the body of the knowledge, this study intends to present an account on the current state of BIM with a focus on barriers and drivers associated with its adoption in Iran based on the perceptions of Iranian construction practitioners. Drawing upon a questionnaire survey completed by 44 construction practitioners and through deploying data visualization alongside statistical analyses, it came to light that industry practitioners in Iran are inexperienced as to BIM's use and the level of BIM implementation in the country is at the lowest level of BIM maturity. That is, 29.5\% of construction companies are involved in some level of BIM adoption whereas $56.8 \%$ have had no exposure to BIM and 36.4\% do not even have any plans to adopt BIM in the near future. The findings also showed that the highest ranked barriers to adoption of BIM in Iran are almost entirely associated with the structure of the Iranian market, the nature of the construction industry and the predominant business environment in the country as well as lack of attention by policy makers and the government. On the other hand, major drivers were found to be associated with monetary gains and enhancing competitiveness in the market. The clear message is that widespread adoption of BIM in Iran will not occur in the absence of a supportive regulatory environment and financial assistance by policy makers. The paper contributes to the field by sharing the preliminary findings of the first study conducted on BIM adoption in Iran, which provides a sound basis for further inquiries on the topic.
\end{abstract}

Keywords: Building Information Modeling (BIM), barriers, drivers, status quo, construction industry, Iran.

\section{Introduction}

Low productivity, high-level of waste, recurrent cost overruns and chronic delays in completion of construction projects are still major problems for the construction industry in Iran (Ghoddousi et al., 2015). This primarily stems from the dominance of traditional methods and lack of attention to embracing the advantages of information communication technology (ICT) in delivering construction projects (Alaghbandrad et al., 2012; Ghoddousi and Hosseini, 2012). In recent years, BIM has emerged as a new methodology, which promises to increase the level of productivity and efficiency in the construction context (Ilozor and Kelly, 2012). Such diverse capabilities of BIM in terms of enhancing performance and productivity have been acknowledged in seminal studies in the construction field (Azhar, 2011;
Sun et al., 2015). Accordingly, a growing interest towards BIM adoption and implementation has been observed throughout the construction industry globally. This includes a wide range of countries in the Middle East, which have attempted to promote BIM implementation on their construction projects (buildingSMART, 2011).

While anecdotal evidence attests to the fact that Iran is lagging in terms of adoption of BIM on construction projects, no research has been undertaken to provide a picture of the current state of BIM use and practice in Iran. Existing studies from the Middle East e.g. (buildingSMART, 2011) have had a bias towards countries in the Persian Gulf and have not covered all the countries in the Middle East (i.e. Iran, Israel and Turkey). Other studies on BIM in developing countries have 
focused on countries other than Iran such as Malaysia, Sri Lanka (Rogers et al., 2015a; Rogers et al., 2015b), and India (Kumar and Mukherjee, 2009). Factors determining the drivers and barriers associated with BIM are shaped by the industry context and have to be investigated within the natural context of a country or company (ArandaMena et al., 2009; Poirier et al., 2015). As such, findings of studies from other countries are not directly applicable to the Iranian context. Moreover, available published studies on BIM in Iran such as the paper by Kiani et al. (2015) merely focused on the application of BIM for scheduling projects, thus the broad status of BIM in Iran has remained unexplored. To the best of the authors' knowledge, there is no available academic enquiry on the current state of BIM in Iran. Against this backdrop, acquiring a comprehensive understanding of the status of BIM in any country has been regarded as a precursor for promotion of BIM (buildingSMART, 2011). This paper aims to address this gap in the body of the knowledge. As the first broad exploratory investigation on BIM in Iran, this research aims to evaluate the current level of awareness and knowledge of BIM among construction practitioners and present a picture of the current state of BIM in Iran. As well as bridging the gap in the body of the knowledge as discussed, the findings can provide support for construction practitioners and policy makers in their move towards harnessing the advantages of BIM within the Iranian construction industry.

\section{Background}

BIM is generally defined as a modeling methodology alongside a number of associated processes deployed to produce, analyze and communicate models of buildings (Eastman et al., 2011). From another perspective, Demian and Walters (2014, p.1154) defined BIM as “...a comprehensive accumulation of information (including documents) about the design, construction and operation of a building, anchored to a geometric (2D/3D) model of the building...".

In the past decade, BIM has been promoted as "one of the most promising developments in the architecture, engineering, and construction (AEC) industry”, capable of reducing project cost, enhancing productivity, quality and decreasing the time for project delivery (Azhar, 2011, p.241). The construction sector in developed economies has observed a growing interest in using BIM due to the myriad of benefits found through its implementation (Eastman et al., 2011). For project planning, design, construction, and maintenance phases, benefits of BIM include resource savings, productivity enhancements (Azhar, 2011) and improvement of quality (Ashcraft, 2008; Chen and Luo, 2014). Implementing BIM fosters a more reliable and timely exchange of information among project stakeholders that accordingly promotes earlier creation of pivotal data necessary for designing and detailing (Ashcraft, 2008; Demian and Walters, 2014). As well, BIM can bring about higher levels of productivity in offsite construction (Demian and Walters, 2014).

In spite of such advantages, the extent to which BIM has permeated the construction industry varies significantly among different countries (Gu and London, 2010). In response to this, investigators in different countries have attempted to provide a picture of the current state of BIM in their countries alongside identifying the barriers to BIM adoption and discovering the drivers that motivate practitioners to use BIM on their projects. As for the drivers, reduction of cost (Azhar, 2011), improvements in information management, increase in design quality and outcomes (Aranda-Mena et al., 2009) and ability to visualize information are regarded as major drivers (Eastman et al., 2011). In essence, economic, technological and societal drivers push the development of BIM with salient examples being the trend of globalization, need for effective collaboration and an increasing demand for sustainable construction (Eastman et al., 2011). Nevertheless, as a counterpoint to the drivers as discussed, a number of barriers obstruct the progress of BIM on construction projects.

According to Gu and London (2010), lack of initiative, knowledge and training, the fragmented nature of the construction industry, varied market readiness across organizations and geographies, and the industry's resistance to change traditional working practices are generic barriers to BIM adoption. Besides, inappropriate business models, regulations and legal and liability risks are identified as generic barriers to BIM adoption across different countries (Eastman et al., 2011). In addition, according to a technical survey focused on BIM flexibility in the design phase, having a more complicated user interface to some extent has jeopardized BIM handling procedure in the construction industry especially within small and medium scale companies (Shourangiz et al., 2011). For the construction industry in the UK, “...the inefficiency in the evaluation of the business value of $\mathrm{BIM}$ and 4D; the shortage of experience within the workforce, and the lack of awareness by stakeholders..." were recognized by Kassem et al. (2012, p.1) as main barriers to BIM adoption.

Likewise, it was observed that BIM implementation still seems a challenging process in North America though the US construction industry, at 50\% implementation, shows a superior position to that of Canada with 30\% adoption rate (McGraw-Hill Construction, 2012). The reason for this gap is a lack of client demand for BIM and established bidding practices based solely on the lowest price rather than considering technical maturity such as BIM awareness and implementation (Porwal and Hewage, 2013). Through a useful illustration of BIM adoption, usage, cost and benefits in Australia, it can be noted that contractors alongside engineers are the primary users of BIM in the Australian construction industry while architects and project clients suffer from a dearth of knowledge toward BIM implementation and its impact (Allen Consulting Group, 2010). Technological barriers and resistance to change in the organizational and functional approaches are again stated at the barriers within Australia (Harris and McCaffer, 2013).

In developing countries, BIM has not been an active field of research with few studies available (Aboushady and Elbarkouky, 2015; Rogers et al., 2015a). The study by buildingSMART (2011) in a number of countries in the Middle East brought to light the fact that higher adoption of BIM is hampered by unavailability of staff and the training required. This also revealed that although the market is avidly interested and optimistic, the construction industry is still in initial stages of its move towards harnessing the benefits of BIM. According to buildingSMART (2011, p.3) "overall the findings 
represent a market that is optimistic and aware, but inexperienced in BIM”.

Nigeria is one of the developing countries experiencing a growth in its construction industry, which contributes $70 \%$ to the nation's fixed capital formation. However, the role of BIM in Nigeria, despite the level of construction, remains far below its current potentials. Abubakar et al. (2014), found that Nigerian design and engineering firms believe that BIM adoption is an innovative approach that requires great level of infrastructure including powerful IT and ICT and that the lack of this infrastructure, in turn, hampers BIM implementation. Likewise, the study on BIM adoption in Cameron revealed that the license fee and lack of largesized project to justify the cost are the main challenges facing practitioners in adoption of BIM (Abanda et al., 2014; Abanda et al., 2016). Exploring BIM adoption in the Malaysian construction industry also shows that although the building economy in Malaysia is rapidly shifting to a thriving industry, it still suffers from an ineffective grasp of BIM concept in its approach. "BIM is seemly new in the Malaysian construction industry and not many companies have implemented BIM in their construction projects and it's hard to get more than five companies that have been implementing BIM" (Bin Zakaria et al., 2013, p.387).

The Russian scenario is similar. Except for some big and multinational companies implementing BIM, there is no conclusive evidence among public or private sectors. As an indication, currently, 23 national projects have been selected to apply BIM in their process and the results of these pilot projects will be used as a guideline on BIM roadmap development for the Russian Federation (Suprun and Stewart, 2015). A survey conducted among AEC firms in India reflects a lower rate of BIM adoption too. Nanajkar and Gao (2014) stressed that only 26 percent of Indian firms have experienced BIM application in their projects in which near half of these respondents have given up its usage as the time goes by.

As shown in Table 1, the findings by Bin Zakaria et al. (2013) showed that lack of knowledge and awareness, absence of support from the government and unavailability of BIM standards and guidelines are among the hurdles to higher level of BIM adoption in Malaysia.
Nanajkar and Gao (2014) investigated the status quo of BIM in India and concluded that the cost of software, the steep learning curve and incompatibility issues among different software packages were perceived as the principal barriers to BIM adoption by Indian construction experts. In China, the main barriers to BIM turned out to be the lack of qualified in-house personnel, unavailability of training/ education, absence of standards, and lack of client demand as identified by Chan (2014). The major barriers to BIM adoption in Nigeria were discovered as the resistance to change in the industry, lack of training, education and cost associated with training, lack of support and involvement of the government (Abubakar et al., 2014).

In essence, major barriers to higher level of BIM adoption stem from the newness of the BIM methodology in developing countries. Lack of awareness and unavailability of training and skilled personnel were observed as the primary barriers to BIM adoption in India, China, Malaysia and Nigeria. Such barriers are exacerbated by the lack of support from policy makers in developing countries and absence of incentives to compensate initial costs of adopting BIM in construction firms (Rogers et al., 2015b). In the same vein, the problem of initial costs and the lack of large-sized construction projects were observed by Abanda et al. (2014) as the main challenges hindering the application of BIM in Cameroon. By the same token, financial problems due to inappropriate legislation were identified as the main obstacles to higher level of BIM adoption in the Russian construction industry (Suprun and Stewart, 2015).

Likewise, BIM remains a novelty within the Iranian construction industry, despite a number of attempts to promote BIM in Iran. These include establishing the BIM Council in Iran (www.iranbimcouncil.com/) and the Iran BIM Association (http://www.ibima.ir/en/) aimed at disseminating the knowledge of BIM among practitioners and expediting the process of BIM assimilation into construction projects. However, studies conducted on BIM in Iran are very few. To the best of the authors' knowledge, except for the study by Kiani et al. (2015), no other empirical study on BIM adoption in Iran is available. As such, the findings of a review of literature reaffirm the discussions regarding the necessity of conducting an exploratory study on BIM in Iran as described next.

Table 1. Barriers to BIM adoption identified in previous studies

\begin{tabular}{|c|c|}
\hline Barriers to BIM & References \\
\hline Lack of knowledge and awareness & (Bin Zakaria et al., 2013; Suprun and Stewart, 2015) \\
\hline Lack of support from policy makers & $\begin{array}{c}\text { (Bin Zakaria et al., 2013; Abubakar et al., 2014; Suprun and } \\
\text { Stewart, 2015) }\end{array}$ \\
\hline Unavailability of standards and guidelines & (Eastman et al., 2011; Bin Zakaria et al., 2013; Chan, 2014) \\
\hline Initial costs & $\begin{array}{l}\text { (buildingSMART, 2011; Abanda et al., 2014; Abubakar et al., } \\
\text { 2014; Rogers et al., 2015b; Abanda et al., 2016) }\end{array}$ \\
\hline Training and learning issues & $\begin{array}{l}\text { (buildingSMART, 2011; Abubakar et al., 2014; Chan, 2014; } \\
\text { Nanajkar and Gao, 2014) }\end{array}$ \\
\hline Incompatibility and interoperability problems & (Nanajkar and Gao, 2014; Rogers et al., 2015b) \\
\hline Lack of demand & $\begin{array}{c}\text { (Abanda et al., 2014; Chan, 2014; Cronk, 2014; Rogers et al., } \\
\text { 2015b) }\end{array}$ \\
\hline Lack of skilled personnel & (buildingSMART, 2011; Chan, 2014; Rogers et al., 2015b) \\
\hline Resistance to change & (Gu and London, 2010; Abubakar et al., 2014; Rogers et al., 2015b) \\
\hline Lack of appropriate IT infrastructures & (Abanda et al., 2014; Abubakar et al., 2014) \\
\hline Substantial economic risk & (Eastman et al., 2011; Suprun and Stewart, 2015) \\
\hline
\end{tabular}




\section{Research Methods}

The questionnaire for the study was divided into four main sections. The first section provided the demographics of respondents, with the $2^{\text {nd }}$ section comprising questions for the evaluation of the current level of BIM adoption on construction projects and awareness of applications of BIM among construction practitioners. The $3^{\text {rd }}$ section presented 4 broad items identified from the literature to elucidate the perceptions of respondents regarding their main drivers for BIM adoption in Iran. As for the $4^{\text {th }}$ section, thirteen barriers to BIM adoption (identified from the literature) were offered and respondents were asked to indicate their perceptions regarding the level of influence of these items in preventing them from BIM adoption on their projects. The questionnaire was designed based on a seven-point Likert rating scale comprising a range from $1=$ very strongly disagree to $7=$ very strongly agree with a neutral phrase in the middle. For designing the questions, the items used in the survey conducted by buildingSMART (2011) were deployed to provide a basis for comparison with other countries in the Middle east. Using a previousapplied survey is justifiable as according to Punch (2005, p. 94) “...we would need good reason for passing over an already existing instrument, particularly if the variable is a central variable in a research area." The developed questionnaire was pilot tested by sending it to four construction practitioners and the feedback obtained was incorporated into the questionnaire prior to delivering the survey to the population of interest.

The target population included contractors and consultants active in all types of construction activities in Tehran. According to the formal classification of contractors currently in place in Iran, construction companies active in government projects are classified into 5 categories. Those in class 1 are the largest in size and are allowed to undertake projects of highest value (Ghoddousi and Hosseini, 2012) while companies in class 5 are usually newly-established companies that carry out small projects. Apart from these 5 categories, some companies are active in housing developments in the private sector. The target population covered both private sector companies and companies from the 5 classes as described above. In addition, consultants are categorized into 3 grades in which grade one consultants are able to provide services for the largest projects. Invitations for participation in this research were sent through the professional association of engineers in Tehran (http://www.tceo.ir/), which is an umbrella organization for all professionals active in construction activities in Tehran. As a result, the study followed a 'quota' sampling approach as termed by Rowley (2014). That is, "cases are selected on the basis of set criteria..., to ensure that the sample has a spread of cases in different categories..." (Rowley, 2014, p.319). As a result, cases in the present study were selected considering their affiliation with the aforementioned association with the aim of covering various construction practitioners in different categories.

Having a population of over 10 million (i.e. 1/7 of Iran's population), Tehran is among the most populated capitals in the world and is Iran's largest city. Due to the concentration of a wide range of socio-economic opportunities, construction practitioners from all professional areas and from other regions of the country migrate to Tehran in search of work which means that around half of construction practitioners in Iran live (and work) in Tehran ((http://www.mrud.ir). Hence, Tehran was regarded as representative of a pool of a wide range of construction practitioners from various backgrounds similar to the assumption made by Ghoddousi et al. (2014). Data collection commenced in January 2015. In May 2015, 560 companies in Tehran had received the invitation, but only 44 had completed the survey. Subsequent follow up contacts with the companies revealed that most of companies had opted not to complete the questionnaire due to the lack of experience and awareness of the concept of BIM.

\section{Results}

\subsection{Respondents’ Profile}

The profile of the respondents as illustrated in Table 2 is reflective of the diversity of respondents in terms of the nature of activity and their role in the construction industry. Around $75 \%$ of respondents were from small companies with fewer than 50 employees. This is no surprise considering the structure of the construction industry in developing countries as according to Edmonds (1979) only around $10 \%$ of companies in the construction industry employ more than 50 personnel. As well, around $23 \%$ were consultants, $61 \%$ contractors and $16 \%$ belonged to the urban housing developers' category. In terms of the length of service in the construction industry, more than $80 \%$ of companies had more than 7 years of experience in the construction industry. As a result, the respondents were deemed adequately knowledgeable and diverse enough to provide information regarding the current state of BIM in the Iranian construction industry.

\subsection{Current State of BIM}

As illustrated in Fig. 1, 28\% was the highest percentage of companies, which claimed to use BIM while around 35\% stated that they have no plans for using BIM. Besides, around 57\% indicated that they have not used BIM on any of their projects where $13 \%$ claimed to use BIM on more than 5 of their projects.

As illustrated in Fig. 2, a major part of respondents was aware of the advantages of BIM in terms of visualization and increasing the speed of project delivery and clash detection. The level of awareness on advantages such as cost savings, enhancing collaboration and quality were lower with the lowest level of awareness was about the role of BIM in reducing design errors. This provides a picture of the perceptions of Iranian construction practitioners of the main applications and advantages envisaged for BIM.

\subsection{Drivers for BIM Adoption}

Cronbach's Alpha coefficient value of 0.77 for the 4 items illustrated in Table 3 exceeded the accepted norm of 0.7 (Nunnally and Bernstein, 1994), thus the reliability of the driver measurements deployed in the questionnaire was deemed acceptable. The items reflective of drivers to BIM were ranked based on the Coefficient of Variation (CV), which was calculated using Eq. (1) as defined by Sheskin (2003).

$$
C V=\frac{\text { Std.Deviation }}{\text { Mean }}
$$

Std. Deviation was defined based on Eq. (2). 
82 M. R. Hosseini, E. Azari, L. Tivendale, S. Banihashemi, and N. Chileshe

$$
\text { Std. Deviation }=\sqrt{\frac{\sum(x-\text { Mean })^{2}}{N}}
$$

Where

$x=$ each value in the sample for variables

$N=$ the number of values (the sample size)

This approach of using the CV obtained by dividing the mean score with the standard deviation has been recommended by Sheskin (2003) and has been accepted within construction research (Ghoddousi and Hosseini, 2012). The CV is reflective of the variability in responses of respondents; hence smaller CVs show higher levels of agreement on the item as indicated by the respondents.
As inferred from Table 3, the first major driver for Iranian construction practitioners for adoption BIM would be its potential for increasing their profit on projects. The second most important driver was identified as the ability of BIM to increase competitiveness in the market.

Client's demand was perceived as the third most influential driver for adoption of BIM by Iranian construction practitioners.

Table 2. Profile of respondents

\begin{tabular}{cccccc}
\hline \multirow{2}{*}{ Role of the company } & \multicolumn{5}{c}{ Number of Employees } \\
\cline { 2 - 5 } & $1-49$ employees & $\begin{array}{c}50-199 \\
\text { employees }\end{array}$ & $\begin{array}{c}\text { 200-999 } \\
\text { employees }\end{array}$ & $\begin{array}{c}\text { More than 1000 } \\
\text { employees }\end{array}$ \\
\hline Consultant Grade 1 & 4 & 1 & 0 & 0 & 5 \\
Consultant Grade 2 & 1 & 0 & 0 & 0 & 1 \\
Consultant Grade 3 & 4 & 0 & 0 & 0 & 4 \\
Contractor Grade 1 & 5 & 4 & 1 & 3 & 13 \\
Contractor Grade 2 & 3 & 0 & 0 & 0 & 3 \\
Contractor Grade 3 & 5 & 1 & 1 & 0 & 7 \\
Contractor Grade 5 & 4 & 0 & 0 & 0 & 4 \\
Urban housing & 7 & 0 & 2 & 0 & 7 \\
Total & 33 & 6 & 3 & 44 \\
\hline
\end{tabular}

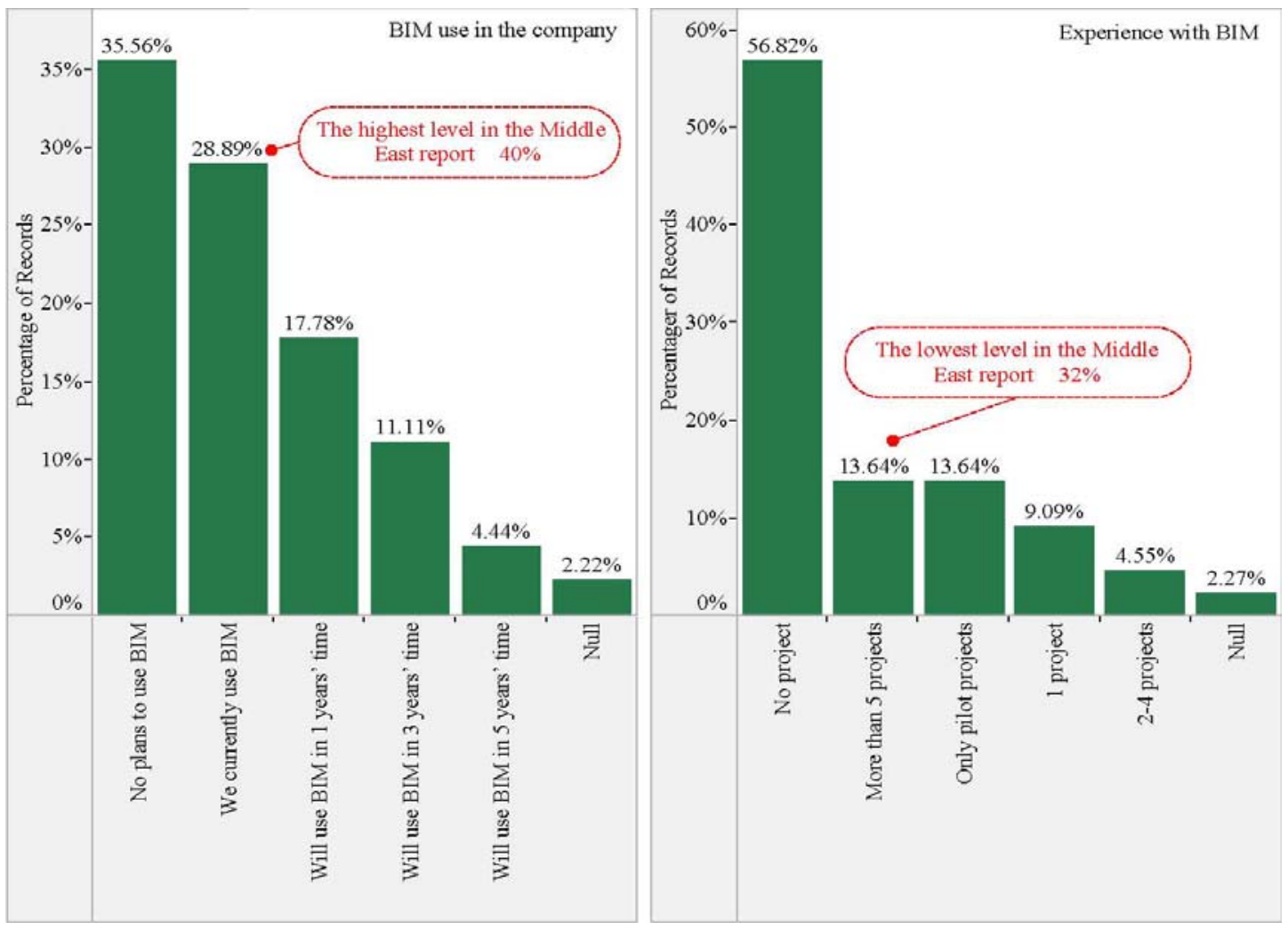

Fig. 1. Level of BIM Use in Iran in comparison to the Middle East report (buildingSMART, 2011) 


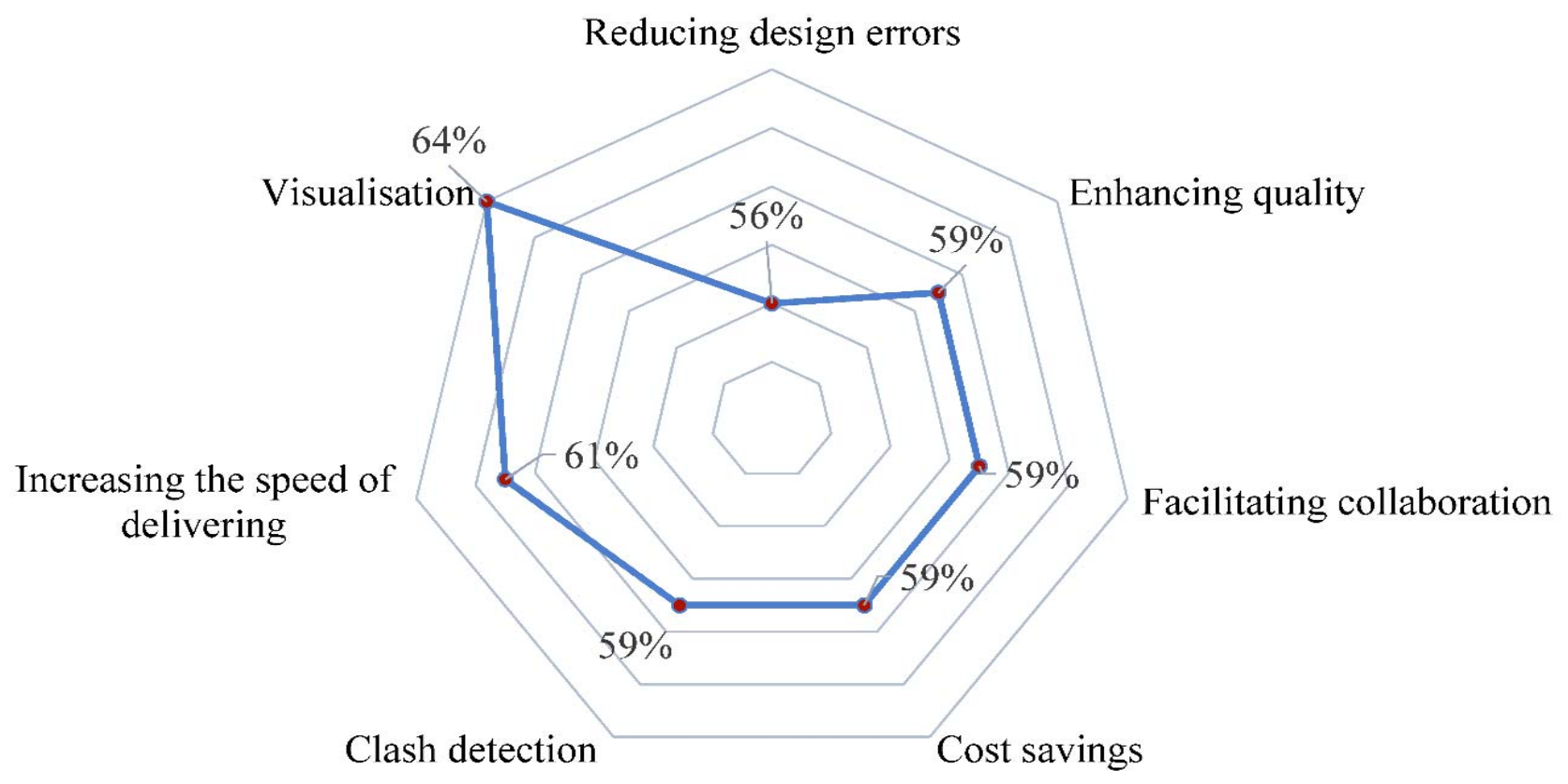

Fig. 2. Percentages of respondents claiming to be aware of various applications of BIM

Table 3. Relative importance of drivers for BIM adoption in Iran

\begin{tabular}{cccccc}
\hline Drivers & $\mathrm{N}$ & Mean & Std. Deviation & CV & Rank \\
\hline Increase in profit & 39 & 6.17 & 0.88 & 0.14 & 1 \\
Increase in competitiveness & 38 & 6.10 & 0.98 & 0.16 & 2 \\
Client's demand & 38 & 5.78 & 1.29 & 0.22 & 3 \\
BIM mandating & 38 & 5.36 & 1.44 & 0.26 & 4 \\
Valid N (listwise) & 36 & & & \\
\hline
\end{tabular}

\subsection{Barriers to BIM Adoption}

The reliability analysis for the measurement items for barriers to BIM (comprising the 13 items) resulted in the Cronbach's Alpha coefficient value of 0.92, which exceeded the accepted norm of 0.7 according to Nunnally and Bernstein (1994) implying the reliability of the measurements deployed in the questionnaire. Table 4 summarizes the results of analysis of barriers to adoption of BIM based on the overall sample of respondents.

As inferred from Table 4, the most important barrier to BIM adoption for Iranian construction practitioners was the lack of support and absence of incentives for promoting BIM by the policy makers in the construction industry.

The second, third and fourth most important barriers all pointed to the lack of knowledge, awareness and experience in adoption of BIM in Iran, which makes companies cautious in adopting BIM. Barriers ranked as the fifth to $9^{\text {th }}$ most important ones were mostly derived by resistance to change within construction companies and the costs associated with establishing BIM on projects. On the other hand, the speed of the internet and the infrastructure required for adopting BIM and collaboration is still a problem within the Iranian construction industry particularly for projects delivered in remote areas due to the immaturity of Iran in implementing ICT solutions (Alaghbandrad et al., 2012). Therefore, the $8^{\text {th }}$ and $9^{\text {th }}$ barriers have roots in problems associated with the infrastructure and the significant costs of providing necessary hardware for adopting BIM on projects as reflected in Table 4.

Thus, slow uptake and general lack of interest in the market deters decision makers from the effort of adopting BIM. The $10^{\text {th }}$ to $13^{\text {th }}$ barriers reflect generic problems and negative perceptions, which hinder higher levels of BIM adoption across a wide range of countries and Iran is no exception. That is, the benefits of BIM are identified and understood only by experienced users of BIM and this lack of experience with BIM in Iran reinforces the lack of awareness of the potential benefits of BIM, which in turn inhibits companies from putting in effort for adopting BIM on their projects. Such problems apply to all parties in the construction supply chain and result in lack of buy-in within the construction industry. 
Table 4. Relative importance of barriers to BIM in Iran

\begin{tabular}{|c|c|c|c|c|c|}
\hline Barriers & $\mathrm{N}$ & Mean & $\begin{array}{c}\text { Std. } \\
\text { Deviation }\end{array}$ & $\mathrm{CV}$ & Rank \\
\hline $\begin{array}{l}\text { Lack of support and incentives from construction } \\
\text { policy makers }\end{array}$ & 38 & 4.78 & 1.43 & 0.299 & 1 \\
\hline We don't know where to start & 40 & 4.50 & 1.41 & 0.314 & 2 \\
\hline Necessary training is not available & 39 & 4.28 & 1.46 & 0.342 & 3 \\
\hline $\begin{array}{l}\text { BIM industry standards and codes are not } \\
\text { available }\end{array}$ & 39 & 4.59 & 1.66 & 0.362 & 4 \\
\hline $\begin{array}{l}\text { Cost associated with purchasing necessary } \\
\text { packages and software }\end{array}$ & 38 & 3.84 & 1.40 & 0.365 & 5 \\
\hline $\begin{array}{l}\text { BIM requires radical changes in our workflow, } \\
\text { practices and procedures }\end{array}$ & 39 & 4.12 & 1.54 & 0.373 & 6 \\
\hline BIM is regarded as a low return-on-investment & 40 & 3.55 & 1.35 & 0.382 & 7 \\
\hline $\begin{array}{l}\text { ICT facilities and internet structure in the country } \\
\text { are not available on projects }\end{array}$ & 39 & 4.23 & 1.64 & 0.388 & 8 \\
\hline Cost of hardware upgrade & 40 & 3.87 & 1.55 & 0.401 & 9 \\
\hline Lack of buy-in from other trades in the market & 40 & 4.10 & 1.66 & 0.405 & 10 \\
\hline Unavailability of skilled staff & 39 & 3.74 & 1.55 & 0.414 & 11 \\
\hline $\begin{array}{c}\text { Benefits of BIM have not been conclusively } \\
\text { proven }\end{array}$ & 40 & 3.60 & 1.49 & 0.416 & 12 \\
\hline $\begin{array}{l}\text { Current methods are adequate for our projects and } \\
\text { BIM is an unnecessary investment }\end{array}$ & 38 & 3.05 & 1.46 & 0.481 & 13 \\
\hline Valid N (listwise) & 33 & & & & \\
\hline
\end{tabular}

\subsection{Effects of respondents' attributes}

One-way analysis of variance (ANOVA) is a procedure that enables researchers of determining if responses provided by different groups of respondents are different in cases participants vary on a single independent variable. In the present study, independent variables were the attributes of respondents in terms of size of the company and role of the company within the Iranian construction industry. Given the relatively small sample size of the study, non-parametric methods were deployed to conduct the analysis as recommended by the seminal study by Siegel and Castellan (1988). Kruskal-Wallis $H$ test provides a non-parametric equivalent for one-way ANOVA with very few assumptions regarding the nature of submitted data (Cronk, 2014). Table 5 illustrates the results of conducting Kruskal-Wallis test for comparing the barriers and drivers among different company sizes and among companies with different roles.

As inferred from Table 5, no significant difference ( $p$ $>0.05)$ was observed among different sizes of Iranian companies in terms of their perceived barriers to adoption of BIM on their projects. As well, difference in size among companies does not seem to be influential in defining the barriers and the driving force for a company in adopting BIM. Nevertheless, for 3 of the drivers for BIM, the role of the company was shown as significant with at least two of the groups differ significantly.

A pairwise comparison reveals which groups have presented different distributions in terms of the role of companies (Cronk, 2014). This showed that contractors and consultants are different in terms of their drivers for BIM adoption. The explanation for this comes from the fact that contractors perceive to gain more benefit from BIM without much change in their routines where consultants have to make huge change to their routines and working practices to adopt BIM. However, both groups perceived clients' demand as an important driver for BIM adoption. This brings to light that similar policies for overcoming barriers towards use of BIM could be equally used for different sizes of companies and for contractors, consultants and practitioners with other roles within the Iranian construction industry. Nevertheless, the drivers are different across different roles, thus the most important drivers for each professional group have to be identified separately based on the nature of their role and business models. 
Table 5. Independent-samples Kruskal-Wallis Test for barriers

\begin{tabular}{|c|c|c|}
\hline \multirow{2}{*}{ Barriers/ Drivers } & Role of company & Size of company \\
\hline & Sig. & Sig. \\
\hline \multicolumn{3}{|l|}{ Barriers } \\
\hline Unavailability of skilled staff & 0.973 & 0.975 \\
\hline $\begin{array}{l}\text { Lack of support and incentives from construction policy } \\
\text { makers }\end{array}$ & 0.402 & 0.717 \\
\hline $\begin{array}{c}\text { Cost associated with purchasing necessary packages and } \\
\text { software }\end{array}$ & 0.373 & 0.191 \\
\hline Necessary training is not available & 0.502 & 0.998 \\
\hline Cost of hardware upgrade & 0.314 & 0.102 \\
\hline BIM industry standards and codes are not available & 0.402 & 0.604 \\
\hline Lack of buy-in from other trades in the market & 0.609 & 0.618 \\
\hline $\begin{array}{l}\text { BIM requires radical changes in our workflow, practices and } \\
\text { procedures }\end{array}$ & 0.272 & 0.086 \\
\hline Benefits of BIM have not been conclusively proven & 0.293 & 0.639 \\
\hline $\begin{array}{l}\text { Current methods are adequate for our projects and BIM is an } \\
\text { unnecessary investment }\end{array}$ & 0.160 & 0.059 \\
\hline $\begin{array}{l}\text { ICT facilities and internet structure in the country are not } \\
\text { available on projects }\end{array}$ & 0.326 & 0.140 \\
\hline BIM is regarded as a low return-on-investment & 0.469 & 0.600 \\
\hline We don't know where to start & 0.656 & 0.383 \\
\hline \multicolumn{3}{|l|}{ Drivers } \\
\hline Increase in profit & 0.031 & 0.922 \\
\hline Increase in competitiveness & 0.047 & 0.937 \\
\hline Client demand & 0.132 & 0.715 \\
\hline BIM mandating & 0.007 & 0.821 \\
\hline
\end{tabular}

\section{Discussions}

\subsection{Current state}

Unlike the report by buildingSMART (2011) that implied the market in the Middle East is interested in BIM, results in Iran manifest a sluggish growth and demand based on the fact that $36.4 \%$ of companies had no plans for BIM while only $18.2 \%$ indicated an interest in using BIM in one year. The experience with BIM in the Middle East turned out to be much higher in comparison to the case of Iran. That was evident where around $32 \%$ of contractors in the buildingSMART (2011) survey claimed to have experience with BIM in more than 5 projects whereas only around $14 \%$ of Iranian companies had used BIM in more than 5 projects. In essence, the findings demonstrate an inexperienced market for BIM in Iran. In addition, the trend of harnessing BIM on projects seems to be slow and lagging behind other countries in the Middle East.

The findings of the study with regard to awareness of major advantages of BIM were in line with the findings observed in China as another new market for BIM. According to Cao et al. (2015) BIM implementation in such new markets are for the most part limited to visualization and clash detection while other non-listed application areas for BIM have remained unexploited and overlooked. More to the point, the findings reveal that BIM in Iran is typically regarded as a tool for 3D presentation of building design whereas BIM utilization is the construction phase is not well-identified within the Iranian construction industry. Hence, it could be concluded that use of BIM within the Iranian construction industry has not gone beyond the lowest level of the maturity model as outlined by $\mathrm{Gu}$ and London (2010). That is, application of BIM does not include collaboration between disciplines and is limited to computer-aided design (CAD) or object-oriented 3D modelling within one discipline. In line with the findings by Rogers et al. (2015a) for Malaysia and Sri Lanka, it could be inferred that level of BIM maturity in Iran is relatively higher than that of Sri Lanka, but much lower than Malaysia.

\subsection{Drivers}

The major drivers for BIM in Iran were found to be associated with profit and enhancement of competitiveness in the market. That is understandable because construction companies adopt new digital technology and make change to their established methods as long as the monetary benefits outweigh the costs (Hosseini et al., 2015). The Iranian construction industry 
has poor profitability and high company failure rates due to irregularity of payments by clients (Ghoddousi and Hosseini, 2012). This is further exacerbated by the recent national global economic downturn due to the widespread recession stemming from international sanctions. The findings were in line with Gilkinson et al. (2015) stating that construction companies' move towards the adoption of BIM is mainly driven by their need to remain competitive in the market. It is widely believed that acquiring BIM will give companies a competitive advantage in the market (Rogers et al., 2015a). This is twice as important for Iranian construction companies because they are badly affected by fierce competition in the national construction market as pointed out by Ghoddousi and Hosseini (2012).

The crucial role of client's demand as observed in Iran resonates with the findings by Rodgers et al. (2015) and Elmualim and Gilder (2014) revealing that the most important catalyst for shifting towards BIM among nonadopters is the pressure from clients. Yet, the findings in Table 3 show that Iranian construction practitioners by far weight financial gains and increase in competitiveness over any mandatory policy when it comes to BIM adoption. As a result, support from the government should be focused in increasing the level of awareness and providing empirical data to support the claims of BIM advantages rather than mandating BIM.

\subsection{Barriers}

Lack of support by policy makers is a major barrier to BIM adoption in Iran. This was in close consistency with the findings of the studies on barriers of BIM in Malaysia (Bin Zakaria et al., 2013) and Nigeria (Abubakar et al., 2014) where the role of government was highlighted in promoting increased levels of BIM adoption in the construction industry. That is, construction companies in Iran, as in other developing countries, usually have to conform to the requirements of the policy makers because their businesses strongly depend on the budget allocated to public sector construction works. Thus, the policy makers could be a major driving force for construction companies to take action as discussed by Kaliba et al. (2009). This becomes understandable in view of the great role of the state and policy makers in the economy and manipulating the business environment in Iran as argued by Alizadeh et al. (2000). Such support could also come in other different forms. For example, governments and policy makers could fund some pilot cases to demonstrate the economic rewards resulted from BIM adoption (Ding et al., 2015).

The lack of knowledge, instructions, education and skilled personnel also were spotted as major barriers in Iran. This resonates with the observations made in Malaysia by Bin Zakaria et al. (2013) denoting that lack of experience and knowledge and unavailability of documents to instruct practitioners are major barriers to widespread adoption of BIM on construction projects in developing countries. Likewise, through a very recent study on BIM adoption in China, the shortage of BIM capabilities in project teams necessitates the development of training schemes for construction practitioners (Ding et al., 2015). This further highlights the role of policy makers in the construction industry because according to the regulations in Iran, the government or its associated professional associations are in charge of preparation of mandatory and instructive documents (such as standards and building codes) regarding construction activities. By releasing national technical codes of BIM conducts, the capacities of the industry to embrace BIM procedures could be further developed. However, construction companies currently evaluate adoption of any novel method such as BIM as difficult and riddled with uncertainties. Thus, they commonly opt not to adopt the innovative method and retain their traditional methods according to the theories of innovation diffusion in the construction industry as asserted by Hosseini et al. (2015).

This finding echoes the observations by Abubakar et al. (2014) in Nigeria implying that one of the most important inhibitors of BIM adoption turned out to be the high level of resistance to change within the construction industry. The structure of the construction industry in Iran is dominated by traditional methods of project delivery (Ghoddousi and Hosseini, 2012). The necessity of radical change in the current working routine that is required for adopting BIM faces a great level of resistance by construction practitioners in the country. Lack of interest in changing the methods is reflected in Fig. 1 where companies indicate they do not consider increasing their BIM use in the near future. Lack of buy-in from trades in the Iranian market further minimizes the adoption rate because construction companies usually are interested in implementing innovative methods adopted by their competitors in the market (Hosseini et al., 2015).

\section{Conclusion}

As the first study on its kind targeting the status quo of BIM in Iran, the findings corroborate the anecdotal evidence denoting low level and undeveloped BIM adoption in the country. The findings bring to light that the Iranian construction industry is significantly lagging behind other countries in the Middle East particularly countries in the Persian Gulf with respect to awareness and adoption of BIM. The findings reveal that level of BIM implementation within the Iranian construction industry is still at the lowest level of maturity, restricted to design phase devoid of collaboration.

The clear message was that in the absence of attention from policy makers and the government, construction companies are not interested in adopting BIM in comparison to the level of interest expressed by construction practitioners in other countries in the Middle East. It would be feasible and justified for the Iranian Government and construction professional associations to provide financial subsidy to assist companies with the costs and research and development requirements of adopting BIM. This should be followed by promotion of delivering projects by BIM in large-sized construction projects as samples, funding research projects to deliver pilot studies using BIM and utilizing mechanisms to disseminate the knowledge gained throughout the whole construction industry. As well, publication of instructive documents to assist construction practitioners in their move towards higher level of BIM maturity on their projects could be of value. In the absence of support and attention from policy makers, the shift of the Iranian construction industry towards adopting BIM would be a slow process with unclear outcomes.

Despite the contributions of the study, the findings should be considered in view of the limitation of the present research. The main limitation of the study is 
having a relatively small sample from Tehran, which might not be representative of the whole construction practitioners in Iran. As well, respondents almost entirely came from small companies with only a few from largesized firms. As a result, findings might not be indicative of the perception of large construction companies in Iran as another limitation for the present study.

Nevertheless, such limitations warrant further research on the topic through using larger samples with respondents from large companies. Conducting case studies on companies currently implementing BIM or attempting to adopt BIM on their projects will provide invaluable information with regard to the challenges and the best practices of adopting BIM.

\section{References}

Abanda, F., Manjia, M., Pettang, C., Tah, J. H., and Nkeng, G. (2016). Building information modelling in Cameroon: overcoming existing challenges. In $\mathrm{M}$. Khosrow-Pour (Ed.), Civil and Environmental Engineering: Concepts, Methodologies, Tools, and Applications. Hershey, PA: Information Resources Management Association (USA).

Abanda, F. H., Manjia, M. B., Pettang, C., Joseph, H. M. T., and Nkeng, G. E. (2014). Building Information Modelling in Cameroon: Overcoming Existing Challenges. International Journal of 3-D Information Modeling (IJ3DIM), 3(4), 1-25.

Aboushady, A. M. and Elbarkouky, M. M. G. (2015). Overview of Building Information Modeling Applications in Construction Projects. Paper presented at the AEI 2015: Birth and Life of the Integrated Building, Milwaukee, Wisconsin.

Abubakar, M., Ibrahim, Y., Kado, D., and Bala, K. (2014). Contractors' Perception of the Factors Affecting Building Information Modelling (BIM) Adoption in the Nigerian Construction Industry. Paper presented at the Computing in Civil and Building Engineering (2014), Orlando, Florida, United States.

Alaghbandrad, A. (2012). Problems and barriers of ICT utilization on Iranian construction sites: Case study on the successful use of ICT in remote construction sites. ITcom, 17, 93-102.

Alizadeh, P., Hakimian, H., and Karshenas, M. (2000). The economy of Iran: The dilemma of an Islamic state. New York, NY: IB Tauris.

Allen Consulting Group, P. L. (2010). Productivity in the Building Networks: Assessing the Impacts of Building Information Models. Sydney.

Aranda-Mena, G., Crawford, J., Chevez, A., and Froese, T. (2009). Building information modelling demystified: does it make business sense to adopt BIM? International Journal of Managing Projects in Business, 2(3), 419-434.

Ashcraft, H. W. (2008). Building information modeling: a framework for collaboration. Construction Lawyer, 28(3), 5-18.

Azhar, S. (2011). Building Information Modeling (BIM): Trends, Benefits, Risks, and Challenges for the AEC Industry. Leadership and Management in Engineering, 11(3), 241-252.

Bin Zakaria, Z., Mohamed Ali, N., Tarmizi Haron, A., Marshall-Ponting, A., and Abd Hamid, Z. (2013). Exploring the adoption of Building Information Modelling (BIM) in the Malaysian construction industry: A qualitative approach. International
Journal of Research in Engineering and Technology, 2(8), 384-395.

buildingSMART (2011). BIM in the Middle East 2011. buildingSMART ME.

Cao, D., Wang, G., Li, H., Skitmore, M., Huang, T., and Zhang, W. (2015). Practices and effectiveness of building information modelling in construction projects in China. Automation in Construction, 49, 113-122.

Chan, C. T. W. (2014) . Barriers of Implementing BIM in Construction Industry from the Designers' Perspective: A Hong Kong Experience Journal of System and Management Sciences, 4(2), 24-40.

Chen, L. and Luo, H. (2014). A BIM-based construction quality management model and its applications. Automation in Construction, 46(0), 64-73.

Cronk, B. C. (2014). How to Use SPSS : a step-by-step guide to analysis and interpretation (8th ed.). Glendale, CA: Pyrczak Pub.

Demian, P. and Walters, D. (2014). The advantages of information management through building information modelling. Construction Management and Economics, 32(12), 1153-1165.

Ding, Z., Zuo, J., Wu, J., Wang, J., Thomson, D., and Hartmann, T. (2015). Key factors for the BIM adoption by architects: a China Study. Engineering, Construction and Architectural Management, 22(6), 732-748.

Eastman, C., Teicholz, P., Sacks, R., and Liston, K. (2011). BIM Handbook : A Guide to Building Information Modeling for Owners, Managers, Designers, Engineers and Contractors, 2 ed. Hoboken: Wiley.

Edmonds, G. A. (1979). Construction Industry in Developing Countries. International Labour Review, 118, 355-370.

Elmualim, A. and Gilder, J. (2014). BIM: innovation in design management, influence and challenges of implementation. Architectural Engineering and Design Management, 10(3-4), 183-199.

Ghoddousi, P., Bahrami, N., Chileshe, N., and Hosseini, M. R. (2014). Mapping site-based construction workers' motivation: Expectancy theory approach. Construction Economics and Building, 14(1), 60-77.

Ghoddousi, P. and Hosseini, M. R. (2012). A Survey of the Factors Affecting the Productivity of Construction Projects in Iran. Technological and Economic Development of Economy, 18(1), 99-116.

Ghoddousi, P., Poorafshar, O., Chileshe, N., and Hosseini, M. R. (2015). Labour productivity in Iranian construction projects: Perceptions of chief executive officers. International Journal of Productivity and Performance Management, 64(6), 811-830.

Gilkinson, N., Raju, P., Kiviniemi, A., and Chapman, C. (2015). Building information modelling: the tide is turning. Proceedings of the Institution of Civil Engineers - Structures and Buildings, 168(2), 81-93.

Gu, N. and London, K. (2010). Understanding and facilitating BIM adoption in the AEC industry. Automation in Construction, 19(8), 988-999.

Harris, F. and McCaffer, R. (2013). Modern construction management: John Wiley \& Sons.

Hosseini, M. R., Chileshe, N., Zuo, J., and Baroudi, B. (2015). Adopting global virtual engineering teams in AEC Projects: A qualitative meta-analysis of innovation diffusion studies. Construction Innovation, 15(2), 151-179. 
Ilozor, B. D. and Kelly, D. J. (2012). Building information modeling and integrated project delivery in the commercial construction industry: A conceptual study. Journal of Engineering, Project, and Production Management, 2(1), 23-36.

Kaliba, C., Muya, M., and Mumba, K. (2009). Cost escalation and schedule delays in road construction projects in Zambia. International Journal of Project Management, 27(5), 522-531.

Kassem, M., Brogden, T., and Dawood, N. (2012). BIM and 4D planning: a holistic study of the barriers and drivers to widespread adoption. KICEM Journal of Construction Engineering and Project Management, 2(4), 1-10.

Kiani, I., Sadeghifam, A. N., Ghomi, S. K., and Marsono, A. K. B. (2015). Barriers to Implementation of Building Information Modeling in Scheduling and Planning Phase in Iran. Australian Journal of Basic and Applied Sciences, 9(5), 91-97.

Kumar, J. V. and Mukherjee, M. (2009). Scope of building information modeling (BIM) in India. Journal of Engineering Science and Technology Review, 2(1), 165-169.

McGraw-Hill Construction (2012). The business value of BIM in North America: multi-year trend analysis and user ratings (2007-2012). Smart Market Report.

Nanajkar, A. and Gao, Z. (2014). BIM Implementation Practices at India's AEC Firms. Paper presented at the International Conference on Construction and Real Estate Management, Kunming, China.

Nunnally, J. C. and Bernstein, I. H. (1994). Psychometric theory. New York: McGraw-Hill.

Poirier, E., Staub-French, S., and Forgues, D. (2015). Embedded contexts of innovation: BIM adoption and implementation for a specialty contracting SME. Construction Innovation, 15(1), 42-65.

Porwal, A. and Hewage, K. N. (2013). Building Information Modeling (BIM) partnering framework for public construction projects. Automation in Construction, 31, 204-214.

Punch, K. F. (2005). Introduction to social research: Quantitative and qualitative approaches. Thousand Oaks, Calif.: Sage Publications Ltd.

Rodgers, C., Hosseini, M. R., Chileshe, N., and Rameezdeen, R. (2015). Building information modelling (BIM) within the Australian construction related small and medium sized enterprises: Awareness, practices and drivers. Paper presented at the The 31st Annual ARCOM Conference, Lincoln, U.K.

Rogers, J., Chong, H.-Y., Jayasena, H. S., Lim, C. C., and Preece, C. (2015)a. BIM Development and Trends in Developing Countries. Sharjah: Bentham Science Publishers.

Rogers, J., Heap-Yih, C., Preece, C., McCaffer, R., and Thomson, D. (2015)b. Adoption of Building Information Modelling technology (BIM): perspectives from Malaysian engineering consulting services firms. Engineering, Construction and Architectural Management, 22(4), 424-445.

Rowley, J. (2014). Designing and using research questionnaires. Management Research Review, 37(3), 308-330.

Sheskin, D. J. (2003). Handbook of Parametric and Nonparametric Statistical Procedures: Third Edition. Florida, USA: CRC Press.
Shourangiz, E., Mohamad, M. I., Hassanabadi, M. S., and Banihashemi, S. (2011). Flexibility of BIM towards Design Change. Paper presented at the 2nd International Conference on Construction and Project Management, IPEDR ACSIT Press, Singapore.

Siegel, S. and Castellan, N. J. (1988). Nonparametric statistics for the behavioral sciences (2nd ed.). New York, NY: McGraw-Hill.

Sun, C., Jiang, S., Skibniewski, M. J., Man, Q., and Shen, L. (2015). A literature review of the factors limiting the application of BIM in the construction industry. Technological and Economic Development of Economy, 1-14.

Suprun, E. V. and Stewart, R. A. (2015). Construction innovation diffusion in the Russian Federation: Barriers, drivers and coping strategies. Construction Innovation, 15(3), 278-312.

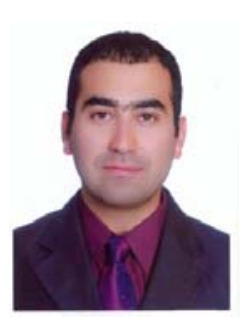

M. Reza Hosseini is currently a lecturer in Construction Management at Deakin University. He is a Civil Engineer and has an MSc in Construction Management. He completed his $\mathrm{PhD}$ at the University of South Australia and his main research fields are virtual design and construction, virtual team working, and collaboration in Building Information Modelling (BIM). He has been a member of the board of directors for Project Management Institute (PMI) Adelaide chapter and a member of Australian Institute of Building (AIB), Australian Institute of Project Management (AIPM) and buildingSMART Australia.

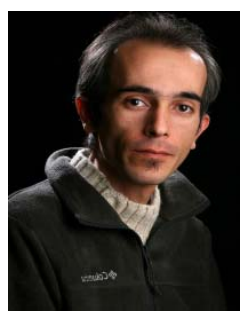

Ehsan Azari is an Iranian Architect and a teacher for Building Information Modeling tools and packages. He has been providing consultancy services on BIM adoption and implementation to a large number of companies and has extensive knowledge in training BIM. His main research areas lie within adoption of BIM for nonadopters and promotion of BIM within Iranian companies.

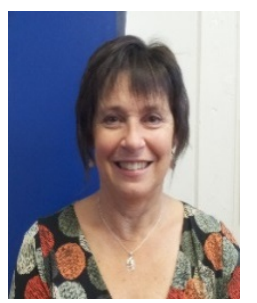

Linda Tivendale is a lecturer at Deakin University, Geelong, Australia. She received her Bachelor of Building (with Honours) from The University of Melbourne and her Master of Building (Research) from Deakin University. Her research is focused on education of construction management professionals, BIM in education and the role of professional organisations. She is the current Vicepresident of the Victorian Chapter of the Australian Institute of Building. 


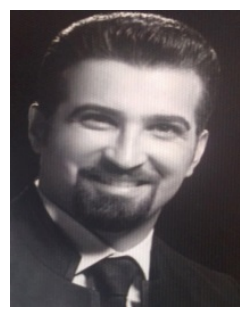

Saeed Banihashemi received his degree in architecture from Tabriz University in Iran in 2008 and master degree in construction and project management from University Technology Malaysia (UTM) in 2012. $\mathrm{He}$ is currently a $\mathrm{PhD}$ candidate of Built Environment in University of Technology Sydney (UTS), working on the integration of Building Information Modelling (BIM) with Artificial Intelligence algorithms toward energy optimization of buildings. His research interests are mainly BIM, machine learning, industrialized building system, energy efficient design and sustainable construction management.

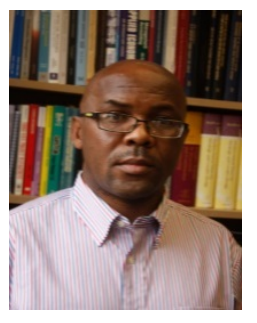

Nicholas Chileshe is a Senior Lecturer in construction and project management at School of Natural and Built Environments, University of South Australia. His current research interests include total quality management, supply chain management, reverse logistics, sustainability, construction management, risk and value management, project management and project success. His research findings have been published in internationally-recognized journals and presented at important conferences, and received a number of awards such as the winner of outstanding reviewer award at the Literati Networks for Excellence $(2008,2010)$ for the Journal of Engineering, Design and Technology and highly commended award paper at the Literati Networks for Excellence 2008 for the Journal of Engineering, Design and Technology.

Currently, Dr Chileshe acts as the member of Editorial Boards for the Journal of Engineering, Design and Technology, International Journal of Construction Supply Chain Management, Journal of Quantity Surveying and Construction Business, and member of Editorial Review Board for the International Journal of Construction and Project. He is also member of the Board of Directors for the Association of Engineering Project, Production Management (EPPM), the International Advisory Board member for the Lean Construction Unit at the Central University of Technology, South Africa, currently the Chair of Chartered Institute of Building (CIOB) Australasian Education Panel. He also regularly reviews proposal for the National Research Foundation (NRF), South Africa, and the Higher Education Academy (United Kingdom [UK]).

Emails can be contacted at Nicholas.chielshe@unisa.edu.au, for information about Dr Nicholas Chileshe, visit http://www.unisanet.unisa.edu.au/staff/homepage.asp?na me=nicholas.chileshe https://staff.qut.edu.au/staff/xiap/ 